\title{
RANCANG BANGUN EKONOMI ISLAM ADIWARMAN KARIM DALAM KAJIAN EPISTOMOLOGI ISLAM
}

\author{
Yoiz Shofwa Shafrani ${ }^{1}$
}

\begin{abstract}
:
The development of Islamic economic thought in Indonesia is still considered only in the banking and financial sector. So, necessary a process to be able to unify the concept of Islamic values and economic concepts so that the Islamic economy can unite at the empirical level. It is hoped that the integration between Islamic values and economic values can broadly describe the concept of Islamic economics. This process can be successful if it is supported by the instruments, especially humans as the main instrument. One of the figures of Islamic economic thought who integrates theory and practical level is Adiwarman Karim. It offers the concept of Islamic economics in all aspects and fields of Islamic economics and business. The thought structure adopted by him is fundamentalist-intellectual-professional, so the concept of Islamic economics offered is the design of Islamic economics. Epistomologically, the background behind Adiwarman getting this idea is based on formal education and the practical world. The methods of obtaining knowledge are historical, figh and economic approaches. Then for the contribution of thought seen in the concept of monetary, a good competitive, foreign exchange control and inflation, money, zakat, Islamic banking, conversion to Islamic banks.
\end{abstract}

Keywords : Epistomologically, Adiwarman Karim, the design of Islamic economics, fundamentalist-intellectual-professional

\section{Pendahuluan}

Perkembangan sistem ekonomi Islam mengalami pasang surut, baik di Indonesia dan seluruh dunia. Kejayaan Islam mengiringi perkembangan sistem ekonomi ini. Berakhirnya kejayaan Islam juga menyebabkan surutnya perkembangan sistem perkonomian Islam $^{2}$. Di Indonesia perkembangan sistem ekonomi Islam dimulai tahun 70an, dimana konsep ekonomi Islam diperkenalkan dengan konsep ekonomi dan bisnis ribawi ${ }^{3}$. Perkembangan yang terjadi, konsep ekonomi Islam masih saja hanya pada bidang keuangan dan perbankan. Menurut Dawam Rahardjo ${ }^{4}$, hal ini disebabkan oleh 2 hal, yaitu satu, petunjuk yang paling terlihat adalah doktrin dari Tuhan dalam Al quran dan sunnah. Kedua, peristiwa

${ }^{1}$ Dosen, IAIN Purwokerto (n.d.).

2 Fatkhul Wahab, "Konsep Dan Kontribusi Pemikiran Adiwarman Azwar KarimTerhadap Perekonomian Indonesia Pendahuluan," IQTISHODIA Jurnal Ekonomi Syariah 1, no. 1 (2016): 59-78.

${ }_{3}$ Pengantar M. Dawam Rahardjo. Menegakkan Syariat Islam di Bidang Ekonomi Islam dalam Adiwarman Karim, Bank Islam : Analisis Fiqih Dan Keuangan (Jakarta: Penerbit IIIT Indonesia, 2003).

${ }^{4}$ Ibid. 
krisis minyak tahun 1974 dan 1979, dimana peristiwa tersebut menyebabkan timbulnya kekayaan finansial berupa petro dollar yang akibat krisis menimbulkan pemikiran untuk diputar di sebuah lembaga keuangan syariah.

Kesan tersebut masih berkembang sampai sekarang, sehingga diperlukan proses untuk dapat menyatukan konsep nilai Islam dan konsep ekonomi agar ekonomi Islam dapat menyatu di tataran empiris. Diharapkan dengan integrasi antara nilai Islam dan nilai ekonomi mampu menggambarkan secara luas dari konsep ekonomi Islam. Proses ini dapat berhasil jika ditunjang oleh instrumeninstrumenya, terutama manusia sebagai instrumen utamanya. Maka perkembangan ekonomi Islam ini tidak akan jauh dari tokoh - tokoh yang menyumbang pemikirannya. Salah satu tokoh yang berpengaruh pada berkembangan ekonomi Islam di Indonesia adalah Adiwarman Karim. Karya-karyanya didasarkan pada pengalaman di bidang pendidikan formal sebagai sarjana ekonomi dan kariernya di bank syariah pertama di Indonesia, Bank Muamalat Indonesia (BMI). Hal yang menarik dari pemikirannya adalah konsep sinerginya atas teori yang didasarkan pada syariat Islam dan tataran praktis sehingga pemikirannya mampu menjawab problematika aspek sosial kemasyarakatan.

\section{Biografi Adiwarman Karim}

Adiwarman Karim lahir pada 29 Juni 1963 di Jakarta. Ayah ibunya berasala dari Minangkabau Padang, Sumatra Barat. Ia lahir dan dibesarkan dalam empat bersaudara. Seluruh saudaranya laki-laki dan sarjana hukum, kecuali Adiwarman yang memilih menjadi sarjana ekonomi. Sejak kecil ia sudah dikenalkan dengan pendidikan agama. Ayahnya pada mulanya adalah seorang jaksa, tapi mengundurkan diri dan lebih memilih menjadi pengacara. Ayahnya merupakan pendiri firma hukum Karim Syah ${ }^{5}$.

Ia memperoleh pendidikan formal di Institut Pertanian Bogor (IPB). Ia masuk ke jurusan sosial ekonomi sehingga mendapatkan gelar Ir. Kemudian ia mengambil kuliah lagi di Fakultas Ekonomi Universitas Indonesia (UI) pada 1983. Lulus dari IPB tahun 1986, Adiwarman menerima tawaran beasiswa untuk melanjutkan pendidikan master bidang keuangan di Universitas Boston, Amerika

\footnotetext{
Wikipedia, "Adiwarman Karim," in Wikipedia Indonesia, n.d., https://id.wikipedia.org/wiki/Adiwarman_Karim.
} 
Serikat. Setelah menyelesaikan tesisnya tentang ekonomi syariah Iran, ia melanjutkan kuliahnya ke Universitas European, Belgia dan meraih gelar MBA pada tahun 1988. Pada tahun 1989, ia menyelesaikan kuliahnya yang sempat terbengkalai di Universitas Indonesia. Pada tahun 1992, ia tamat dari Boston University dengan gelar MAEP6.

Karier Adiwarman dimulai sebagai pegawai di Badan Perencanaan Pembangunan Nasional, kemudian pada tahu 1992 ia mulai berkarier di bidang perbankan syariah yaitu mejadi staf litbang di Bank Muamalat ${ }^{7}$. Karier Adiwarman semakin melonjak di Bank Muamalat sampai menjadi wakil direktur pada tahun 2000. Namun akhirnya ia memutuskan untuk resign dari BMI, meskipun dengan pergolakan hati. Keputusannya itu yang pada akhirnya membawa semangat untuk dapat mengembangkan unit usaha syariah pada setiap bank konvensional ${ }^{8}$.

Bersamaan dengan kariernya di BMI, Adiwarman beserta cendikiawan Muslim Indonesia dan beberapa tokoh mendirikan The International Institute of Islamic Thought (IIIT) Indonesia. Kemudian pada tahun 2001 Adiwarman mendirikan perusahaan konsultan Karim Business Consulting. Pada awal berdiri saat itu, perusahaan yang bergabung hanyalah BMI. Tetapi seiring perkembangan sistem ekonomi Islam maka sekarang ini perusahaan konsultan tersebut menjadi rujukan untuk lembaga - lembaga keuangan syariah ${ }^{9}$.

Semangat Adiwarman dalam menggerakan ekonomi Islam dimulai dari kariernya di BMI. Setelah menjalani karier di BMI selama enam tahun, ia mulai menyadari bahwa lembaga keuangan syariah inilah yang dapat menggambarkan implementasi sistem ekonomi Islam. Sehingga pasca kariernya di BMI ia berusaha menyebarkan semangat pergerakan ekonomi Islam tidak hanya pada tataran praktis juga teoritis. Ia menjadi dosen di beberapa universitas dan aktif dalam penulisan karya ilmiah baik berupa buku maupun artikel. Banyak sekali kepercayaan yang harus diembannya. Antara lain Wakil Ketua Badan Pelaksana Harian Dewan Syariah Nasional MUI (2010-2015), anggota dari Internasional Islamic Financial Market (IIFM) Shari'ah Advisor Panel (2011-2012), Wakil Komite Tetap

\footnotetext{
${ }^{6}$ Ibid.

${ }^{7}$ Ibid.

${ }^{8}$ Wahab, "Konsep Dan Kontribusi Pemikiran Adiwarman Azwar KarimTerhadap Perekonomian Indonesia Pendahuluan."

${ }^{9}$ Wahab.
} 
Keuangan Syariah Kamar Dagang dan Industri Indonesia (KADIN) dan Dewan Pengawas Syariah pada berbagai Lembaga Keuangan Syariah seperti Asuransi Great Eastern Syariah (2002-2012), Asuransi Prudential Life (2007-2012), Bank Danamon Syariah (2002-2010), HSBC Syariah Indonesia (2008-2013), BNP Paribas Investment Parterners (2007-2012) dan perusahaan UFO Multi level marketing ${ }^{10}$.

\section{Karya karya}

Meskipun respon yang diberikan oleh masyarakat tentang gagasan sistem ekonomi Islam adalah pesimis, tetapi tidak menyurutkan semangat adiwarman dalam membuat karya berupa tulisan dalam bentuk buku maupun artikel ilmiah. Sampai tahun 2015, untuk artikel ilmiah yang sudah ditulis oleh adiwarman lebih dari 50 artikel tentang ekonomi Islam yang disajikan dalam berbagai acara seperti Konferensi Ekonomi Islam Internasional Ketiga, Keempat dan Kelima yang disponsori oleh Islamic Development Bank (IDB) dan Koferensi tahunan Internasional Western Economic Association yang ke-76 ${ }^{11}$.

Untuk karya Adiwarman yang berupa buku diantaranya adalah

a. Sejarah Pemikiran Ekonomi Islam (2001), buku ini menjelaskan tentang penelurusuran sejarah pemikirian tokoh-tokoh Islam. Hasilnya adalah ditemukannya distorsi sejarah, di mana banyak sekali hasil pemikiran dari pemikir dari barat yang sebenarnya merupakan pemikiran dari tokoh- tokoh muslim ${ }^{12}$.

b. Ekonomi Mikro Islami (2002). Buku ini menjelaskan konsep, variabel dan teori - teori ekonomi yang telah diidentifikasi pemikir ekonomi muslim seperti Ibn Taimiyah, Ibn Khaldun, Al Ghazali dan lainnya. Buku ini terus mengalami perubahan untuk tujuan pengembangan. Pada setiap edisi terdapat perubahan

${ }^{10}$ MA Dr Oni Sahroni and M.A.E.P Ir. Adiwarman A Karim, S.E., M.M.A, Maqashid Bisnis Dan Keuangan Islam (Jakarta: PT. Raja Grafindo Persada, Jakarta, 2015).

${ }^{11}$ Dr Oni Sahroni and Ir. Adiwarman A Karim, S.E., M.M.A.

12 M.A.E.P Ir. Adiwarman A Karim, S.E., M.M.A, Sejarah Pemikiran Ekonomi Islam, pertama (Jakarta: Rajawali Press, 2001). 
mulai dari materi dan untuk edisi ketiga ada penambahan satu bab baru, yaitu bab yang membahasa tentang struktur pasar dan persaingan harga ${ }^{13}$.

c. Ekonomi Islam : Suatu Kajian Makro (2002), buku ini menjelaskan tentang konsep ekonomi Islam, dengan runtutan penjelasan kajian ekonomi makro konvensional kemudian diikuti penjelasan ekonomi makro Islam. Hal ini dimaksudkan untuk memberikan science of economics dan phylosophy of economics. Pendekatan ini memungkinkan untuk dapat membandingkan pemikiran ekonomi konvesional dengan ekonomi makros Islami dalam setiap aspek ekonomi dan bisnis ${ }^{14}$.

Untuk ketiga buku di atas merupakan hasil karya ketika berjuang bersama kawan dan tokoh cendikiawan muslin yang tergabung dalam Internasional Institut of Islamic Thougt (IIIT) Indonesia, yang disebut sebagai partisipasi IIIT dalam pergulatan diskursus ekonomi syariah dan sebagai bahan kajian dalam kuliah informal Islamic Economic bekerja sama dengan Universitas Brawijaya, Universitas Gadjah Mada, Universitas Indonesia dan Universitas Islam Negeri Syarif Hidayatullah Jakarta yang diselenggarakan setiap tahun selama enam bulan ${ }^{15}$. Kemudian untuk buku yang lain adalah sebagai berikut :

a. Bank Islam, Analisis Fiqih dan keuangan (2003), buku ini mengalami perubahan dan perkembangan setiap tahunnya. Hingga pada edisi ketiga diterbitkan dalam bahasa Inggris. Namun karena respon pasar maka diterbitkan pula dalam bahasa Indonesia. Buku ini menjelaskan dan memberikan argumentasi - argumentasi yang kuat dan ilmiah berdasarkan ilmu fiqh dan teori keuangan mengenai filosofis dan praktek bank Islam. Salah satu filosofi dasar ajaran Islam dalam kegiatan ekonomi dan bisnis, adalah larangan untuk berbuat curang dan dzalim. Sehingga semua transaksi yang dilakukan oleh seorang muslim harus berdasarkan prinsip rela sama rela (an taroddin mikum) dan tidak boleh ada pihak yang mendzalimi dan didzalimi. Prinsip dasar ini mempunyai impikasi luas dalam bidang ekonomi dan bisnis, termasuk dalam praktek perbankan. Salah satu kritik Islam terhadap praktik bank konvensional

${ }^{13}$ M.A.E.P Ir. Adiwarman A Karim, S.E., M.M.A, Bank Islam : Analisis Fiqih Dan Keuangan, Edisi Keti (Jakarta: PT. Raja Grafindo Persada, Jakarta, 2004).

${ }^{14}$ M.A.E.P Ir. Adiwarman A Karim, S.E., M.M.A, Ekonomi Makro Islami, Kedua (Jakarta: PT. Raja Grafindo Persada, Jakarta, 2007).

${ }^{15}$ Karim, Bank Islam : Analisis Fiqih Dan Keuangan.

\section{el- JIZYA}


adalah dilanggarnya prinsip al kharaj bi al-dhaman (hasil usaha muncul bersama biaya) dan prinsip al ghunmu bi al-ghurmi (untung muncul bersama risiko) ${ }^{16}$.

b. Maqashid Bisnis dan keuangan Islam (2015). Buku ini mengulas betapa pentingnya maqashid syariah sehingga dijadikan salah satu syarat menjadi ahli ijtihad dan ahli fatwa agar produk fatwa itu dapat sesuai dengan tujuan "keinginan" Allah SWT. Karena sesungguhnya ada tujuan (maqashid) Allah SWT di balik ketentuan hukum bisnis dan keuangan syariah. Dalam konteks bisnis dan keuangan syariah, fiqih maqashid ini mensinergikan antara nash dan kepentingan pasar, memastikan bahwa kepentingan pasar adalah kepentingan yang sebenarnya, bahwa kepentingan ekonomi adalah kepentingan masyarakat banyak, dan kepentingan bisnis adalah kepentingan jangka oanjang sesuai dengan rumusan maqashid. Jadi buku ini menjelaskan hal - hal penting dalam maqashid syariah, diantaranya dhowabith maqaashid syariah, cara menggali maqashid syariah baik mikro dan makro juga menjelaskan contoh penerpan ijtihad maqashidi dalam fatwa - fatwa lembaga fikih seperti Dewan Syariah Nasional ${ }^{17}$.

\section{Kajian Epistomologi}

Epistimologi adalah salah satu cabang dari filsafat yang merupakan proses pengkajian sebuah ilmu pengetahuan berdasarkan sumber pengetahuan tersebut, struktur dari ilmu pengetahuan tersebut, cara memperoleh pengetahuan tersebut dan bagaimana menvalidasi kesahihan dari ilmu tersebut ${ }^{18}$. Maka apabila dalam konteks kajian epistimologi untuk pemikiran tokoh akan disandarkan dari aspek - aspek tersebut.

a. Struktur pemikiran

Pola pemikiran yang dikembangkan oleh Adiwarman dikelompokkan dalam kelompok fundamentalis, karena dalam setiap gagasannya selalu

\footnotetext{
${ }^{16}$ Karim.

${ }^{17}$ Dr Oni Sahroni and Ir. Adiwarman A Karim, S.E., M.M.A, Maqashid Bisnis Dan Keuangan Islam.

${ }^{18}$ Agus Arwani, "Epistemologi Hukum Ekonomi Islam (Muamalah)," Religia 15, no. 1 (2017), https://doi.org/10.28918/religia.v15i1.126.
} 
memperjuangkan untuk dapat sesuai dengan syariat Islam ${ }^{19}$. Menurut Dawan Rahardjo $^{20}$, ideologi fundamentalisme ini tidak bermakna tunggal. Hal ini banyak ditampakkan dari sinonimya, seperti Islam radikal, faham salafiyah, Islam ekstrim, gerakan revivalis, meskipun tidak semuanya memiliki makna yang identik akan tetapi memiliki pengertian yang saling tumpah tindih. Makna yang sama adalah pada tujuan untuk menegakkan syariat Islam, yang membedakan adalah metode perjuangnnya. Untuk pola pemikiran Adiwarman sendiri menurut Amarodin ${ }^{21}$, termasuk dalam kelompok fundamentalis Intelektual profesional. Maknanya pola pemikiran Adiwarman dari paham fundamentalisme dengan menelaah tataran praktek dan teorinya.

Bangunan epistomologi dari Adiwarman tergambar dalam bentuk rancang bangun ekonomi Islam, bahwa bangunan ekonomi Islam didasarkan atas lima nilai universal, yaitu

a. Tauhid (Keimanan), kata ini menunjukkan bahwa manusia bersaksi tiada sesuatupun yang layak untuk disembah selain Allah. Kesadaran Adiwarman bahwa Allah menciptakan semua alam semesta dan isinya serta memilikinya, menghasilkan nilai awal dari rancang bangunnya.

b. 'Adl (Keadilan), Allah menciptakan alam semesta dan isinya ini memperlakukan semua dengan perlakuan yang sama. Dalam Al quran banyak diperintahkan agar manusia selalu bersifat adil. Adil ini didefinisikan sebagai perlakuan tidak menzalimi dan tidak dizalimi. Maknanya kata adil ini dalam konteks ekonomi ini adalah manusia akan memperoleh hasil sesuai dengan usahanya tanpa harus mengedepankan egonya.

c. Nubuwwah (Kenabian), dimensi ini memberikan contoh perilaku manusia yang ideal. Sifat yang dimiliki oleh nabi Muhammad Saw adalah Siddiq (jujur), Amanah (bertanggungjawab), Fathanah (kecerdikan, kebijakan) dan Tabligh (komunikasi, keterbukaan, pemasaran). Dengan konteks sifat idela

19 Muchamad Amarodin, "Konstruksi Sistem Ekonomi Islam Pemikiran Tokoh Ekonomi Islam Kontemporer," 4 Eksyar 5, no. 1 (2018): 41-55.

${ }^{20}$ Pengantar Dawam Rahardjo dalam Karim, Bank Islam : Analisis Fiqih Dan Keuangan.

${ }^{21}$ Amarodin, "Konstruksi Sistem Ekonomi Islam Pemikiran Tokoh Ekonomi Islam Kontemporer." 
inilah diharapkan pelaku ekonomi dan bisnis mampu menjadi profesional sesuai syariat Islam.

d. Khilafah (Pemerintahan), Peran Pemerintah dalam sistem ekonomi Islam dalah untuk dapat menjamin bahwa tatanan perekonomian sebuah pemerintahan dalam berjalan sesuai dengan syariah dan memastikan untuk tidak terjadi pelanggaran terhadap hak - hak asasi manusia.

e. Ma'ad (Hasil), meskipun secara harifiah diartikan sebagai kebangkitan, tetapi disini artinya kembali. Makna yang akan disampaikan adalah pandangan yang khas dari seorang muslim tentang dunia dan akhirat :"dunia sebagai ladang akhirat". Allah menjelaskan bahwa setiap manusia harus berjuang, demi mendapatkakn ganjaran. Jadi implikasi dalam ekonomi bahwa dengan perjuangan maka akan dapat meligitimasi adalanya laba/profit.
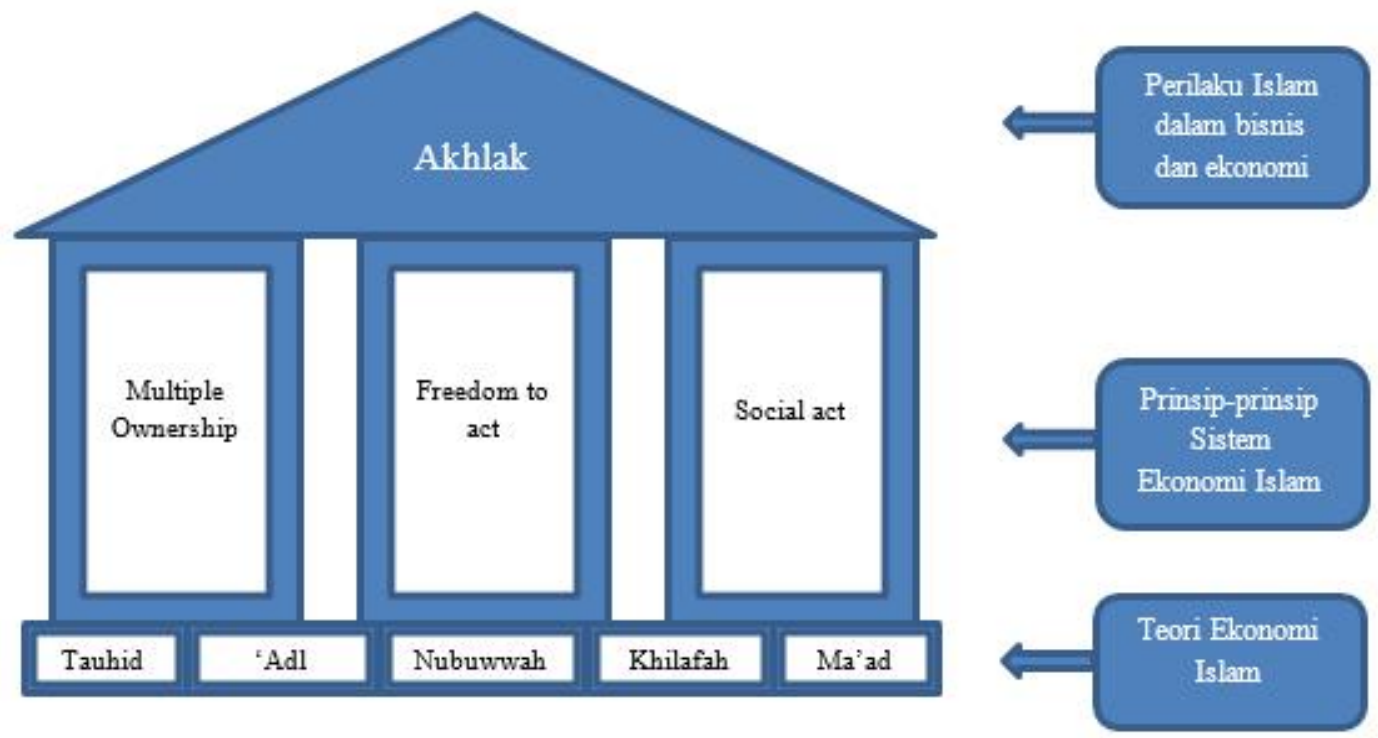

Gambar 1. Rancang Bangun Ekonomi Islam ${ }^{22}$

Kelima nilai yang ditawarkan oleh Adiwarman tentunya tidak muncul begitu saja. Tetapi melalui proses berpikir, mengamati dan adanya pengalaman yang dialami sehingga mampu menghasilkan nilai - nilai tersebut. Jika dilihat dari nilai- nilai yang ada, Adiwarman terlihat bersandar pada teks (nash). Karena misalnya prinsip Tauhid ini muncul dari teks yang jelas yaitu al Quran dan

${ }^{22}$ M.A.E.P Ir. Adiwarman A Karim, S.E., M.M.A, Ekonomi Mikro Islami, Edisi Keti (Jakarta: PT. Raja Grafindo Persada, Jakarta, 2007). Hlm 34. 
hadis. Kemudian nilai Nubuwwah dan khilafah, juga muncul dari adanya penelusuran pada teks yaitu al quran dan hadis. Jika dilihat dari pendekatan metode epistimologinya, maka dalam memunculkan nilai ini sesuai dengan model bayani. Model epistimologi bayani ini menyandarkan pada pembacaan teks, sehingga dalam proses memunculkan pengetahuan, pembacaan teks secara benar menjadi sangat penting karena berkaitan dengan sah atau tidaknya pengetahuan tersebut menjadi dasar hukum ${ }^{23}$. Meskipun sebenarnya ketika nilai-nilai tersebut muncul sebagai oengetahuan tidak akan lepas dari unsur akal atau logika. Contohnya konsep tauhid muncul dari al quran, tetapi pada penerapan dan dihubungkan dengan ekonomi tetap menggunakan unsur logika. Bahwa nilai tauhid itu akan tercermin pada para pelaku bisnis. Sehingga segala usaha yang dilakukan oleh manusia tidak akan terlepas dari intervensi Tuhan sebagai penciptanya.

Kelanjutan dari 5 nilai dari rancang bangun ekonomi Islam adalah adanya tiga prinsip turunannya yang menjadi tunas dari sistem ekonomi Islam, yaitu multitype ownership, freedom to act, dan sosial justice.

Multiptype ownership dilahirkan dari konsep tauhid dan adil. Prinsip ini memberikan makna bahwa kepemilikian mutlak atas alam semesta adalah Allah (pemilik primer), sedangkan manusia diberi kuasa untuk mengelola (pemilik sekunder). Inilah melegalkan akan kepemilikan atas sumber daya. Namun demi keadilan untuk sumber daya yang penting dan menguasai hajat hidup orang banyak dikuasai oleh negara. Freedom to act dilahirkan dari nilai nubuwwah, karena dengan penerapan sifat nabi yang empat tadi sudah menjadi kepribadian dari pelaku ekonomi dan bisnis yang kemudian digabungkan dengan nilai khilafah (good governance) akan melahirkan prinsip freedom to act. Prinsip ini akan menciptakan mekanisme pasar yang Islami dan perekonomian yang tidak terjadi distorsi (proses penzaliman).

Penggabungan nilai khilafah dan nilai ma'ad melahirkan prinsip sosial justice (keadilan sosial). Bahwa semua sistem ekonomi memiliki tujuan yang sama, yaitu menciptkan perekonomian yang adil. Akan tetapi tidak semua sistem perekonomian tersebut dapat berjalan dengan konsisten. Dalam Islam, keadilan

23 A Khudori Sholeh, "MODEL-MODEL EPISTEMOLOGI ISLAM A Khudori Soleh," Psikoislamika 2, no. 2 (2005). 
diartikan dengan suka sama suka (anatarraddiminkum) dan satu pihak tidak menzalimi pihak lain (latazlimuna wa la tuzlamun). Islam menganut sistem mekanisme pasar, tetapi tidak semuanya diserahkan pada mekanisme pasar. Pemikiran Adiwarman tentang turunan dari 5 nilai pondasi dasarnya adalah dengan menggabungkan metode bayani dan metode burhani. Metode burhani merupakan metode epistimologi yang mengedepankan akal dan logika. Metode ini tidak mengandalkan teks sebagai sandaran melainkan pengalaman (experience) yang dirasakan dan dialami oleh indra manusia ${ }^{24}$.

Dapat dilihat dari munculnya pemikiran atas multiple owner, pengalaman dan kenyataan yang dihadapi oleh adiwarman adalah pada mekanisme pasar yang cenderung membentuk pola monopoli yang tidak sehat seperti permaianan harga, penimbunan barang, pemutusan rantai distribusi untuk merusak harga. Maka Adiwarman juga bersandar pada Al quran dan hadis, untuk dapat membuat wacana dalam menanggulangi masalah tersebut. Pengamatan dan pengalaman akan dianalisis secara logika kemudian disandarkan kembali pada teks.

Kesimpulan dari rancang bangun ini adalah dibangunnya payung besar untuk memayungi semua nilai tersebut, yaitu konsep akhlak. Nilai inilah yang menduduki posisi puncak, karena akhlak ini lah yang menjadi tujuan Islam dan dakwah para Nabi, yaitu menyempurnakan akhlak manusia sehingga dapat menjadi pedoman bagi pelaku ekonomi dan bisnis ${ }^{25}$.

b. Metode memperoleh pengetahuan

Jika dilihat dari karya-karya yang dihasilkan maka dalam mengeluarkan pemikiran-pemikirannya, Adiwarman menggunakan tiga pendekatan, yaitu pendekatan sejarah, pendekatan fiqh dan pendekatan ekonomi ${ }^{26}$. Melalui pendekatan sejarah, Adiwarman menelaah pemikiran-pemikiran tokoh ekonomi Islam dan membadingkannya dengan empiris sistem ekonomi yang ada. Dari

24 Ibid.

${ }^{25}$ Ir. Adiwarman A Karim, S.E., M.M.A, Ekonomi Mikro Islami. Hlm 34.

${ }^{26}$ Siti Mardiyah, "Efisiensi Alokasi Dalam Pandangan Adiwarman Karim," Islamic Banking 2, no. 1 Agustus (2016): 11-22. 
penelaahannya tersebut, adiwarman menemukan adanya distorsi sejarah ${ }^{27}$. Banyak sekali pemikiran - pemikiran tentang ekonomi yang dikeluarkan dan dikenalkan oleh ahli- ahli dari barat. Setelah ditelusuri ternyata pemikiranpemikiran tersebut bukan-lah asli pemikiran mereka melainkan pemikiran dari tokoh dan ahli Islam yang kemudian direduksi dan diklaim menjadi pemikirian dan ahli ekonomi barat.

Kemudian dengan pendekatan fiqh, Adiwarman berpendapat bahwa kajian fiqih tidaklah sempit hanya pada bidang 'ubudiyah tetapi juga mencakup atas seluruh bidang kehidupan manusia termasuk sosial kemasyarakatan ${ }^{28}$. Oleh karena itu dengan pendekatan ini, Adiwarman menjelaskan dalam sebuah konsep fiqih realitas ( fiqh al-waqi'iy). Menurutnya dengan fiqih ini akan lebih mampu menjawab pertanyaan-pertanyaan terkait dengan problematika kontemporer kehidupan sosial masyarakat.

Pendekatan fiqih Adiwarman tidak lepas dengan pendekatan ekonomi. Untuk dapat menganalisis realitas - realitas ekonomi, maka digunakan fiqih untuk dapat menjadi dasar dalam perspektif ekonomi ${ }^{29}$. Contohnya ketika menjelaskan tentang analisis kurva indefference, maka kemudian dikaitkan bahwa penggambaran kurva ini tidak akan sama untuk setiap komoditi. Bahwa dalam teori rasionalis Islam dijelaskan tidak semua komoditi bersifat sama, ada barang halal dan haram. Artinya bentuk dari kurva indefference untuk setiap jenis sifat barang itu akan berkebalikan ${ }^{30}$.

Melihat proses berpikir dan wacana dari Adiwarman, jika dilihat dari metode epistimologi maka dia menggabungkan metode bayani dan burhani. Metode bayani merupakan proses berpikir yang bersandar pada pembacaan teks atau dengan kata lain bahwa ilmu pengetahuan dapat muncul sekaligus pada waktu membaca teks tanpa perlu memahami. Akan tetapi pemunculan ilmu pengetahuan ini juga tidak serta merta menghilangkan akal dan ratio dalam membaca teks tersebut ${ }^{31}$. Sedangkan untuk metode burhani, dalam

${ }^{27}$ Wahab, "Konsep Dan Kontribusi Pemikiran Adiwarman Azwar KarimTerhadap Perekonomian Indonesia Pendahuluan."

${ }^{28}$ Mardiyah, "Efisiensi Alokasi Dalam Pandangan Adiwarman Karim."

${ }^{29}$ Ibid.

${ }^{30}$ Ir. Adiwarman A Karim, S.E., M.M.A, Ekonomi Mikro Islami.hlm 68

${ }^{31}$ Sholeh, "MODEL-MODEL EPISTEMOLOGI ISLAM A Khudori Soleh.” . Hlm. 196

\section{el- JIZYA}


memunculkan ilmu pengetahuan menggunakan akal rasio. Kombinasi inilah yang digunakan oleh Adi warman untuk memunculkan pengetahuannya. Dalam memunculkan konsep rancang bangun ekonomi Islam, dia mengkombinasikan teks alquran, hadist dan tataran empiris ekonomi. Bahwa pada setiap memunculkan nilai di dalam rancang bangunnya, dia bersandar dulu pada teks al quran dan hadis, baru kemudian dinalarkan dengan logika yang diperoleh dari pengamatan dan pengalamannya. Mengedepankan pada al quran dan hadis sangat jelas terlihat pada pemikiran Adiwarman yang tercermin dalam karyakaryanya. Seperti nilai tauhid, nubuwwah dan khilafah, terlihat bahwa nilai ini muncul karena ada di dalam al quran dan hadis. Proses ini tidak berhenti ipada pembacaan teks saja. Tetapi jika merunut dari proses yang dilakukan dalam metode bayani, yaitu pertama adalah membaca teks dengan benar kemudian kedua membuat analisis dan pemahaman atas teks itu dengan nalar atau logika ${ }^{32}$.

c. Validasi kesahihan

Pemikiran Adiwarman membawa implikasi yang besar dalam perkembangan sistem ekonomi Islam di Indonesia. Menurut Fathul Wahab ${ }^{33}$ pemikiran Adiwarman berkontribusi pada tujuh dimensi dalam sistem ekonomi, pertama dalam sistem moneter. Sistem moneter yang ditawarakan oleh Adiwarman berupa pengembangan sistem moneter pada pengendalian perputaran uang yang dipercepat. Caranya adalah menumbuhkan sektor usaha riil dengan adanya mekanisme akad qard (pinjaman) dan akad kerjasama syirkah dan mudharabah, dengan ketentuan tidak diperbolehkan adanya penimbunan likuiditas atau disalurkan dengan konsep bunga. Hal ini terbukti dengan tumbuhnya lembaga keuangan syariah yang memiliki tujuan mengembangkan sektor riil terutama kalangan UMKM melalui mekanisme bantuan penyaluran pembiayaan. Kedua, menciptakan persaingan dan atau monopoli yang sehat. Dalam Islam ada kebebasan dalam hal berusaha, artinya setiap orang memiliki hak untuk berbisnis. Apabila kemudian bisnis tersebut akhirnya memunculkan monopoli, maka penentuan harga pun harus menjadi pertimbangan. Maka peran Pemerintah dalam hal ini diperlukan untuk dapat

${ }^{32}$ Sholeh.

${ }^{33}$ Wahab, "Konsep Dan Kontribusi Pemikiran Adiwarman Azwar KarimTerhadap Perekonomian Indonesia Pendahuluan." 
campur tangan secara tidak langsung melindungi hak penjual dan hak pembeli dalam konteks persaingan tersebut.

Ketiga, kontrol devisa dan ekonomi Islam. Konsep ini masih kurang dikenal, ini merupakan ide dari IMF pada saat negara - negara di Asia mengalami krisis moneter yaitu dengan menetapkan kontrol devisa dan sistem kurs tetap. Sebenarnya pada masa Rasul, kebijakan sistem devisa bebas sudah diperlakukan. Pada masa sekarang ini, ada risiko yang harus dihadapi ketika sistem ini diberlakukan, yaitu modal - modal besar akan secara bebas keluar. Dalam realitasnya, risiko tersebut akan berlangsung singkat, karena pada akhirnya investor akan segera masuk ke pasar yang cenderung aman. Keempat, konsep uang yang dijelaskan oleh Adiwarman adalah flow concepts dan public goods ${ }^{34}$. Dalam pemikirannya ini, Adiwarman menyamakan bawah aliran uang seperti aliran air. Di mana ketika air mengalir ke suatu wadah, maka aliran air yang menggenang disebut capital dan wadahnya disebut public goods. Oleh karena itu ketika air ini menggenang terlalu lama akan menyebabkan air menjadi kotor karena sama dengan proses penimbunan, begitu pula uang. Sedangkan jika dialirkan justru akan menjadi sebuah kebermanfaatan.

Kelima, zakat. Wacana tentang konsep zakat yang digunakan sebagai alat untuk memberantas kemiskinan. Sehingga saat ini lembaga pengelola zakat ini berkembang di Indonesia. Keenam, Perbankan Syariah. Karier Adiwarman pada bank syariah pertama di Indonesia, yaitu BMI membawa pemikiran tentang konsep bank syariah semakin berkembang. Bagaimana akad-akad yang diimplementasikan di dunia perbankan syariah dapat menjadi solusi untuk dapat mengembangkan sektor riil. Ketujuh, konversi menjadi bank syariah. Setelah perkembangan BMI sebagai bank syariah pertama di Indonesia dan wacana ekonomi Islam yang terus digaungkan maka muncullah bank-bank syariah yang merupakan hasil konversi dari perbankan konvesional.

Kontribusi pemikiran Adiwarman telah banyak memberikan manfaat pada perkembangan sistem ekonomi Islam. Hal ini dikarenakan pada pemikirannya tidak hanya memberikan pemikiran berupa wacana atau teori tetapi juga diperbandingkan dengan tataran praktis. Jadi antara aspek teoritis dan praktis harus

${ }^{34}$ N. Eva Fauziah Mochamad Fadlyllah, Zaini Abdul Malik, "Implementasi Uang Sebagai Flow Concept Dan Public Goods Dalam Ekonomi Islam Di Indonesia (Studi Atas Pemikiran Ekonomi Islam Adiwarman A Karim)," in Prosiding Hukum Ekonomi Syariah (Spesia, 2015), 35-42, https://doi.org/http://dx.doi.org/10.29313/syariah.v0i0.464. 
sinergis berjalam bersama. Oleh Amarodin ${ }^{35}$ gerakan ini disebut sebagai gerakan Ekonomi Islam Indonesia (harakah Indonesiyah) yang diintegrasikan dengan intelektual. Sehingga gerakan ini dapat berkontribusi langsung pada pergerakan ekonomi Islam di Indonesia secara riil.

\section{Simpulan}

Integrasi antara nilai Islam dan nilai ekonomi mampu menggambarkan secara luas dari konsep ekonomi Islam. Proses ini dapat berhasil jika ditunjang oleh instrumen-instrumennya, terutama manusia sebagai instrumen utamanya. Salah satu tokoh pemikiran ekonomi Islam yang mengintegrasikan antara teori dan tataran praktis adalah Adiwarman Karim. Ia menawarkan konsep ekonomi Islam di semua aspek dan bidang ekonomi dan bisnis Islam. Dengan struktur pemikiran yang di anut olehnya adalah fundamentalis-intelektual-profesional, maka konsep ekonomi Islam yang ditawarkan adalah rancang bangun ekonomi Islam. Secara epistomologi, yang melatar belakangi Adiwarman memperoleh pemikiran tersebut berdasarkan dari pendidikan formil dan dunia praktis. Melihat proses berpikir dan wacana dari Adiwarman, jika dilihat dari metode epistimologi maka dia menggabungkan metode bayani dan burhani. Untuk metode memperoleh pengetahuannya adalah dengan pendekatan sejarah, fiqih dan ekonomi. Kemudian untuk kontribusi pemikirannya terlihat pada konsep moneter, monopoli dan persaingan yang sehat, kontrol devisa dan inflasi, uang, zakat, perbankan Islam, konversi ke bank Islam.

\section{Daftar Pustaka}

Amarodin, Muchamad. "Konstruksi Sistem Ekonomi Islam Pemikiran Tokoh Ekonomi Islam Kontemporer." 4 Eksyar 5, no. 1 (2018): 41-55.

Arwani, Agus. "Epistemologi Hukum Ekonomi Islam (Muamalah).” Religia 15, no. 1

(2017). https://doi.org/10.28918/religia.v15i1.126.

Dosen. IAIN Purwokerto (n.d.).

Dr Oni Sahroni, MA, and M.A.E.P Ir. Adiwarman A Karim, S.E., M.M.A. Maqashid

Bisnis Dan Keuangan Islam. Jakarta: PT. Raja Grafindo Persada, Jakarta, 2015.

Ir. Adiwarman A Karim, S.E., M.M.A, M.A.E.P. Bank Islam : Analisis Fiqih Dan

Keuangan. Edisi Keti. Jakarta: PT. Raja Grafindo Persada, Jakarta, 2004.

\section{—. Ekonomi Makro Islami. Kedua. Jakarta: PT. Raja Grafindo Persada, Jakarta,} 2007.

—. Ekonomi Mikro Islami. Edisi Keti. Jakarta: PT. Raja Grafindo Persada, Jakarta, Hlm 52 .

${ }^{35}$ Amarodin, "Konstruksi Sistem Ekonomi Islam Pemikiran Tokoh Ekonomi Islam Kontemporer."

\section{el- JIZYA}


2007.

Sejarah Pemikiran Ekonomi Islam. Pertama. Jakarta: Rajawali Press, 2001.

Karim, Adiwarman. Bank Islam : Analisis Fiqih Dan Keuangan. Jakarta: Penerbit IIIT Indonesia, 2003.

Mardiyah, Siti. "Efisiensi Alokasi Dalam Pandangan Adiwarman Karim." Islamic Banking 2, no. 1 Agustus (2016): 11-22.

Mochamad Fadlyllah, Zaini Abdul Malik, N. Eva Fauziah. "IMPLEMENTASI UANG SEBAGAI FLOW CONCEPT DAN PUBLIC GOODS DALAM EKONOMI ISLAM DI INDONESIA (STUDI ATAS PEMIKIRAN EKONOMI ISLAM ADIWARMAN A KARIM).” In Prosiding Hukum Ekonomi Syariah, 35-42. Spesia, 2015. https://doi.org/http://dx.doi.org/10.29313/syariah.v0i0.464.

Sholeh, A Khudori. "MODEL-MODEL EPISTEMOLOGI ISLAM A Khudori Soleh." Psikoislamika 2, no. 2 (2005).

Wahab, Fatkhul. "Konsep Dan Kontribusi Pemikiran Adiwarman Azwar KarimTerhadap Perekonomian Indonesia Pendahuluan." IQTISHODIA Jurnal Ekonomi Syariah 1, no. 1 (2016): 59-78.

Wikipedia. “Adiwarman Karim.” In Wikipedia Indonesia, n.d. https://id.wikipedia.org/wiki/Adiwarman_Karim. 